\title{
Xanthium strumarium L. antimicrobial activity and carboxyatractyloside analysis through electrospray ionization mass spectrometry
}

\author{
SCHERER, R. ${ }^{1}$; DUARTE, M.C.T. ${ }^{2}$; CATHARINO, R.R. ${ }^{3}$; NACHTIGALL, F.M. ${ }^{3}$; EBERLIN, M.N. ${ }^{3}$; TEIXEIRAFILHO, \\ J.'; GODOY, H.T. \\ Department of Food Science, Faculty of Food Engineering. State University of Campinas/UNICAMP, Rua Monteiro \\ Lobato 80, 13083-970, Campinas-SP, Brazil, Caixa Postal 6121 *helena@fea.unicamp.br Research Centerfor Chemistry, \\ Biology and Agriculture - CPQBA/UNICAMP; Rua Alexandre Cazelatto, 999, Vila Betel, Paulínia - SP, Brasil, Caixa \\ Postal $6171^{3}$ ThoMSon Mass Spectrometry Laboratory, Institute of Chemistry, UNICAMP, Rua Monteiro Lobato 130, \\ 13083-970, Campinas-SP, Brasil, Caixa Postal 6023; ${ }^{4}$ Department of water and soil, Faculty of Agricultural Engineering, \\ UNICAMP, Rua Cândido Rondon, 501. 13083-875, Campinas-SP, Brasil, Caixa Postal 6011.
}

\begin{abstract}
The aim of this work was to evaluate the antimicrobial activity of Xanthium strumarium L. leaf extracts against Staphylococcus aureus, Escherichia coli, Salmonella typhimurium, Pseudomonas aeruginosa and Clostridium perfringens, as well as to investigate the presence of the toxic compound carboxyatractyloside in different plant parts. $S$. aureus and $C$. perfringens were more sensitive to non-polar than to polar fractions, and there was no difference between extracts for the remaining bacteria. All extracts had strong antimicrobial activity against the evaluated microorganisms. Carboxyatractyloside was found in cotyledons and seeds but not in adult leaves and burrs. Thus, only Xanthium strumarium leaves in adult stage can be used for medicinal purposes.
\end{abstract}

Key words: cocklebur, antimicrobial activity, medicinal plants

RESUMO: Atividade antimicrobiana e análise de carboxiatractilosideo por espectrometria de massas com ionização por electrospray de Xanthium strumarium L. O objetivo do presente trabalho foi avaliar a atividade antimicrobiana de extratos de folhas de Xanthium strumarium L. sobre os microrganismos Staphylococcus aureus, Escherichia coli, Salmonella thyphimurium, Pseudomonas aeruginosa e Clostridium perfringens, bem como verificar a presença do composto tóxico carboxiatractilosideo em diferentes partes da planta. As bactérias $S$. aureus e $C$. perfringens foram mais sensíveis às frações não polares do que as polares, sendo que para as outras bactérias não foi verificada diferença entre os extratos. Todos os extratos apresentaram uma forte ação antimicrobiana sobre os microrganismos avaliados. O carboxiatractilosideo foi encontrado nos cotilédones e nas sementes da planta, entretanto, não foi encontrado nas folhas em estádio adulto e na carapaça espinhosa que envolve a semente. Portanto, somente as folhas de Xanthium strumarium na fase adulta podem ser utilizadas para o uso medicinal.

Palavras-chave: carrapicho, atividade antimicrobiana, plantas medicinais

\section{INTRODUCTION}

Cocklebur (Xanthium strumarium L.) is an herbaceous annual plant of worldwide distribution. The plant is erect, up to $2.5 \mathrm{~m}$ tall, and presents blotched purple stems. Its leaves are dark green on the upper surface, similar in shape to grape leaves, $15 \mathrm{~cm}$ in diameter and roughly textured with minute bristles. The flowers are inconspicuous, both male and female, occurring in leaf axils towards the end of the branches.
In addition, the flowers develop into hard woody burrs (fruits), $1.2 \mathrm{~cm}$ to $2 \mathrm{~cm}$ long, with numerous hooked spines. $X$. strumarium is extremely competitive with other crops. It has long been considered one of the worst weeds in soybean plantations (Bozsa \& Oliver, 1993).

Some biological properties of Xanthium strumarium L. have been reported, such as antiulcerogenic (Favier et al., 2005), antitrypanosomal

Recebido para publicação em 25/04/2008

Aceito para publicação em 13/11/2008

Rev. Bras. PI. Med., Botucatu, v.11, n.2, p.159-163, 2009. 
(Talakal et al., 1995), anthelmintic (Sharma et al., 2003), anti-inflammatory (Kim et al., 2005; Yadava \& Jharbade, 2007), diuretic (Nieves et al., 1999), antileishmanial, antifungal (Lavault et al., 2005) and hypoglycemic actions (Hsu et al., 2000), besides inhibition of cultured human tumor cell proliferation (Kim et al., 2003) and a significant depressant action on the central nervous system (Mandal et al., 2001).

Previous studies have reported that $X$. strumarium induces intoxication and can be lethal to cattle (Colodel et al., 2000), sheep (Loretti et al., 1999), pigs (Stuart et al., 1981) and humans (Turgut et al., 2005). Also, the consumption of fruits (burrs) and cotyledonary-stage leaves (two-leaf stage) leads to hepatic necrosis and myocardial injury in humans. The toxic principle in $X$. strumarium poison was isolated and identified as carboxyatractyloside (CAT) (Cole et al., 1980), a highly selective inhibitor of oxidative phosphorylation (Scott et al., 1993).

The chemical composition of $X$. strumarium includes phenolic compounds like chlorogenic and ferulic acids, thiazinediones (Han et al., 2006; Qin et al., 2006), triterpenoid saponin (Yadava \& Jharbade, 2007), CAT (Cole et al., 1980), xanthanolide sesquiterpene lactones (8-epi-xanthatin and 8-epixanthatin epoxide) (Kim et al., 2003), several xanthanolides (Riscala et al., 1994), beta-sitosterol (Bisht et al., 1977), strumasterol (C-24 epimer of stigamsterol) (Bisht et al., 1978), monoterpene and sesquiterpene hydrocarbons (Taher et al., 1985), caffeic acid, 1,3,5-tri-O-caffeoyl quinic acid, 1,5-di-Ocaffeoyl quinic acid (Sheu et al., 2003).

However, there are no reports about the antimicrobial activities of $X$. strumarium extracts against human pathogenic microorganisms such as Escherichia coli and about the presence of the toxic compound in different plant parts. Therefore, the aim of this work was to investigate the antimicrobial activities of several extracts from $X$. strumarium adult leaves against Staphylococcus aureus, Escherichia coli, Salmonella typhimurium, Pseudomonas aeruginosa and Clostridium perfringens, as well as to verify the presence of CAT in different plant parts.

\section{MATERIALAND METHOD}

\section{Reagents and standards}

Chromatographic grade methanol (Tedia, Fairfield, OH, USA), ammonium hydroxide (Merck, Darmstadt, Germany), nutrient agar (Merck, Germany), dimethyl sulfoxide (DMSO) (Sigma, USA), triphenyl tetrazolium chloride (TTC) (Merck, Germany), culture medium (Mueller-Hinton 2.1\%, Merck, Germany) were used. The antibiotics amoxicillin, enrofloxacin, erythromycin, lincomycin, tetracycline, oxytetracycline, penicillin G, spiramycin, sulfadiazine and sulfanilamide were purchased from Sigma (USA). CAT was from Calbiochem (Darmstadt, Germany).

\section{Plant material}

Xanthium strumarium (common name: cocklebur, Family: Asteraceae) used in this work was cultivated in the experimental field of the School of Agricultural Engineering (FEAGRI), State University of Campinas (UNICAMP, Campinas, São Paulo State, Brazil). A voucher specimen was deposited at the State University of Campinas Herbarium under the number 134865 and identified by Dr. Washington M. F. Neto (curator). The leaves were separated, dried in a tray drier with air circulation at $45^{\circ} \mathrm{C}$ (Marconi, model 035 , Piracicaba, São Paulo State, Brazil), packed in dark plastic bags and stored in a domestic freezer at $-20^{\circ} \mathrm{C}$ until extracted. Before extraction, the material was triturated in a domestic food processor (Wallita, model Master, São Paulo, SP) and the particles from 24 48 mesh selected using a magnetic agitator (Bertel, Model 1868, Caieiras, São Paulo State, Brazil).

\section{Extracts}

Extracts were obtained using 3 different extraction methods and 4 different solvents, in triplicate. The employed methods were maceration (1), dynamic maceration (2) and soxhlet (3). Solvents were $80 \%$ ethanol $(A), 80 \%$ methanol $(B)$, ethyl acetate (C) and dichloromethane/chloroform (1:1) (D). Maceration was done with $20 \mathrm{~g}$ plus $100 \mathrm{~mL}$ of the different solvents, resulting in the extracts $1 \mathrm{~A}, 1 \mathrm{~B}$, $1 \mathrm{C}$ and $1 \mathrm{D}$. After 7 days under periodic agitation, the extracts were filtered through paper filter and the residue again extracted with $100 \mathrm{~mL}$ of the respective solvents for 10 min under agitation. Both fractions were then blended and evaporated to dryness at $38^{\circ} \mathrm{C}$ under vacuum. Dynamic maceration was carried out with $20 \mathrm{~g}$ plus $100 \mathrm{~mL}$ of the different solvents, yielding the extracts $2 \mathrm{~A}, 2 \mathrm{~B}, 2 \mathrm{C}$ and $2 \mathrm{D}$. After $3 \mathrm{~h}$ agitation, the extracts were filtered through paper filter and the residue again extracted with $100 \mathrm{~mL}$ of the respective solvents for $1 \mathrm{~h}$ under agitation. Both fractions were then blended and evaporated to dryness at $38^{\circ} \mathrm{C}$ under vacuum. Soxhlet method was carried out in a soxhlet apparatus with $15 \mathrm{~g}$ for $5 \mathrm{~h}$ extraction with the solvents $A, B$ and $C$, resulting in the extracts $3 A, 3 B$ and $3 C$. The extracts were dried to dryness at $38^{\circ} \mathrm{C}$ under vacuum. All extracts were stored in a domestic freezer at $-20^{\circ} \mathrm{C}$ until analysis.

\section{Antimicrobial activity}

Minimal inhibitory concentration (MIC) tests were carried out according to the NCCLS (National Committee of Laboratory Standards, 2003) (31) using a tissue culture test plate (96 wells). Staphylococcus aureus (ATCC 6538), Escherichia coli (isolated from swine), Salmonella typhimurium (ATCC 14028), 
Pseudomonas aeruginosa (ATCC 13388) and Clostridium perfringens (ATCC 1324) were used in the tests. The microorganisms were grown overnight at $36^{\circ} \mathrm{C}$ in nutrient agar plates under aerobiosis, except for Clostridium perfringens, cultivated in thioglycollate broth under anaerobiosis. The inoculum for the assays was prepared by diluting scraped cell mass in $0.85 \%$ $\mathrm{NaCl}$ solution, adjusted to the McFarland scale 0.5 . Cell suspensions were finally diluted to $10^{4} \mathrm{CFU} \mathrm{mL}^{-1}$ for the assays. The extracts and the antibiotics were diluted in DMSO and stored at $-20^{\circ} \mathrm{C}$ until used. The final concentrations of the extracts were 1.8, 1.5, 1.2, $1.0,0.8,0.6,0.4$ and $0.2 \mathrm{mg} \mathrm{mL}^{-1}$, whereas serial dilutions of the antibiotics were prepared between 0.25 and $0.00195 \mathrm{mg} \mathrm{mL}^{-1}$. The inoculum was added to all wells and the plates were incubated at $36^{\circ} \mathrm{C}$ for $24 \mathrm{~h}$. To verify the sterility of extracts and culture medium (Mueller-Hinton $2.1 \%$ ), as well as the viability of microorganisms, a control test was done with all test plates. Antimicrobial activity was detected by adding $0.05 \mathrm{~mL}$ of an aqueous $0.5 \%$ triphenyl tetrazolium chloride (TTC) solution. MIC was defined as the lowest oil or extract concentration that visually inhibited growth, indicated by TCC staining (dead cells are not stained by TTC).

\section{CAT analysis}

Adult and cotyledonary-stage dried leaves, seeds and burrs were extracted with $50 \%$ methanol (100 $\mathrm{mg}$ to $5 \mathrm{~mL}$ ) for 20 minutes in ultrasound and filtered in $0.5 \mathrm{~mm}$ membrane (FHLP13, Millipore). Plant extract samples were analyzed through direct infusion ESI-MS using a syringe pump (Harvard Apparatus) at a flow rate of $10 \mu \mathrm{L} \mathrm{min}{ }^{-1}$. ESI-MS fingerprints and ESI-MS/MS in the negative ion mode were obtained using a hybrid high-resolution and highaccuracy $(5 \mathrm{ppm})$ Micromass Q-TOF mass spectrometer. Capillary and cone voltages were set to $-3000 \mathrm{~V}$ and $-50 \mathrm{~V}$, respectively, at a desolvation temperature of $100^{\circ} \mathrm{C}$. One milliliter of each sample was added to $10 \mathrm{~mL}$ of a solution containing $70 \%(\mathrm{v} /$ v) chromatographic grade methanol and $30 \%(\mathrm{v} / \mathrm{v})$ deionized water and $5 \mu \mathrm{L}$ ammonium hydroxide per milliliter. Fingerprint mass spectra were obtained in the $\mathrm{m} / \mathrm{z}$ range between 650 and 920 .

\section{RESULT AND DISCUSSION}

Table 1 shows the antimicrobial activity of $X$. strumarium extracts and antibiotics. There were no differences between $X$. strumarium extracts, except for $S$. aureus and $C$. perfringens, which were affected by the used solvent but not by the extraction method.

The extracting solvents ethyl acetate $(\mathrm{C})$ and dichloromethane/chloroform (1:1) (D) were more effective than $80 \%$ ethanol $(A)$ and $80 \%$ methanol (B). Since $S$. aureus and $C$. perfringens are gram-positive bacteria, some cell wall active compounds have probably concentrated in the non-polar fraction; however, further studies are needed to prove this statement. S. typhimurium and C. perfringens were more resistant to $X$. strumarium methanolic and ethanolic extracts than $E$. coli and $P$. aeruginosa.

TABLE 1. Minimal inhibitory concentration (MIC, $\mathrm{mg} \mathrm{mL}^{-1}$ ) of Xanthium strumarium extracts and antibiotics.

\begin{tabular}{cccccc}
\hline Extract/antibiotic & S. aureus & E. coli & P. aeruginosa & S. thyphimurium & C. perfringens \\
\hline 1A & $0.400-0.600$ & $0.400-0.600$ & $0.400-0.600$ & $0.600-0.800$ & $0.600-0.800$ \\
1B & $0.400-0.600$ & $0.400-0.600$ & $0.400-0.600$ & $0.600-0.800$ & $0.600-0.800$ \\
1C & $0.200-0.400$ & $0.400-0.600$ & $0.400-0.600$ & $0.600-0.800$ & $0.400-0.600$ \\
1D & $0.200-0.400$ & $0.400-0.600$ & $0.400-0.600$ & $0.600-0.800$ & $0.400-0.600$ \\
2A & $0.400-0.600$ & $0.400-0.600$ & $0.400-0.600$ & $0.600-0.800$ & $0.600-0.800$ \\
2B & $0.400-0.600$ & $0.400-0.600$ & $0.400-0.600$ & $0.600-0.800$ & $0.600-0.800$ \\
2C & $0.200-0.400$ & $0.400-0.600$ & $0.400-0.600$ & $0.600-0.800$ & $0.400-0.600$ \\
2D & $0.200-0.400$ & $0.400-0.600$ & $0.400-0.600$ & $0.600-0.800$ & $0.400-0.600$ \\
3A & $0.400-0.600$ & $0.400-0.600$ & $0.400-0.600$ & $0.600-0.800$ & $0.600-0.800$ \\
3B & $0.400-0.600$ & $0.400-0.600$ & $0.400-0.600$ & $0.600-0.800$ & $0.600-0.800$ \\
3C & $0.200-0.400$ & $0.400-0.600$ & $0.400-0.600$ & $0.600-0.800$ & $0.400-0.600$ \\
Penicilin G & $*$ & $0.008-0.015$ & $0.062-0.125$ & $0.062-0.125$ & $0.062-0.125$ \\
Enrofloxacin & $*$ & $*$ & $*$ & $0.004-0.008$ & $*$ \\
Erythromycin & $*$ & $*$ & $0.031-0.062$ & $0.031-0.062$ & $0.031-0.062$ \\
Sulfadiazine & $0.062-0.125$ & $0.004-0.008$ & $0.062-0.125$ & $0.062-0.125$ & $0.062-0.125$ \\
Oxytetracycline & $*$ & $0.008-0.015$ & $0.062-0.125$ & $0.062-0.125$ & $0.062-0.125$ \\
Lincomycin & $*$ & $0.031-0.062$ & $0.031-0.062$ & $0.031-0.062$ & $0.031-0.062$ \\
Spiramycin & $0.002-0.004$ & $0.004-0.008$ & $0.062-0.125$ & $0.062-0.125$ & $0.062-0.125$ \\
Amoxicillin & $*$ & $0.031-0.062$ & $0.062-0.125$ & $0.062-0.125$ & $0.031-0.062$ \\
Tetracycline & $*$ & $*$ & $0.031-0.062$ & $0.031-0.062$ & $0.008-0.015$ \\
Sulfanilamide & $0.062-0.125$ & $0.004-0.008$ & $0.062-0.125$ & $0.062-0.125$ & $0.062-0.125$ \\
\hline
\end{tabular}

1: maceration; 2: dynamic maceration; 3: soxhlet; A: $80 \%$ ethanol; B: $80 \%$ methanol; C: ethyl acetate; D: chloroform/dichloromethane $(1: 1) .{ }^{*}<0.0019 \mathrm{mg} \mathrm{mL}^{-1}$. 
Xanthatin was found at small quantities in $X$. strumarium essential oil. This compound was isolated from $X$. spinosum $L$. extracts and was active against Colletotrichum gloeosporioides, Trichothecium roseum, Bacillus cereus and S. aureus (Ginesta-Peris et al., 1994). A previous study reported that cinnamic acid was effective against $E$. coli, $P$. aeruginosa, $S$. aureus and Salmonella sp. and MIC values were 1.0 $\mathrm{mg} \mathrm{mL}^{-1}$ for all strains (Chang et al., 2001). Cinnamic acid was found in $X$. strumarium extracts between 22

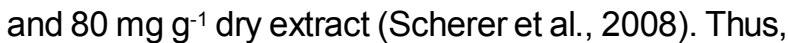
the compounds xanthatin and cinnamic acid could have contributed to the antimicrobial property of $X$. strumarium.

Staphylococcus aureus was the most susceptible to the tested antibiotics, followed by $E$. coli. MIC values for $S$. aureus were below $0.0019 \mathrm{mg}$ $\mathrm{mL}^{-1}$ for penicillin $\mathrm{G}$, enrofloxacin, erythromycin, oxytetracycline, lincomycin, amoxicillin and tetracycline. Enrofloxacin was the most effective antibiotic against all tested strains, followed by tetracycline and erythromycin, respectively (Table 1). On the other hand, sulfanilamide and sulfadiazine showed the highest MIC values for $S$. aureus.

Duarte et al. (2005) proposed a classification for plant material based on MIC results: strong inhibitors when MIC is below $0.5 \mathrm{mg} \mathrm{mL}^{-1}$; moderate inhibitors when MIC is between 0.6 and $1.5 \mathrm{mg} \mathrm{mL}^{-1}$; and weak inhibitors when MIC is above $1.6 \mathrm{mg} \mathrm{mL}^{-1}$. Thus, considering this classification, all $X$. strumarium extracts showed potential antimicrobial activity against the evaluated microorganisms (Table 1).

Figure $1 \mathrm{~A}$ shows the ESI-MS fingerprint of $X$. strumarium seed. Note the ion of $\mathrm{m} / \mathrm{z} 769$ which corresponds to the deprotonated molecule of carboxyatractyloside. Its ESI-MS/MS (Figure 1B)

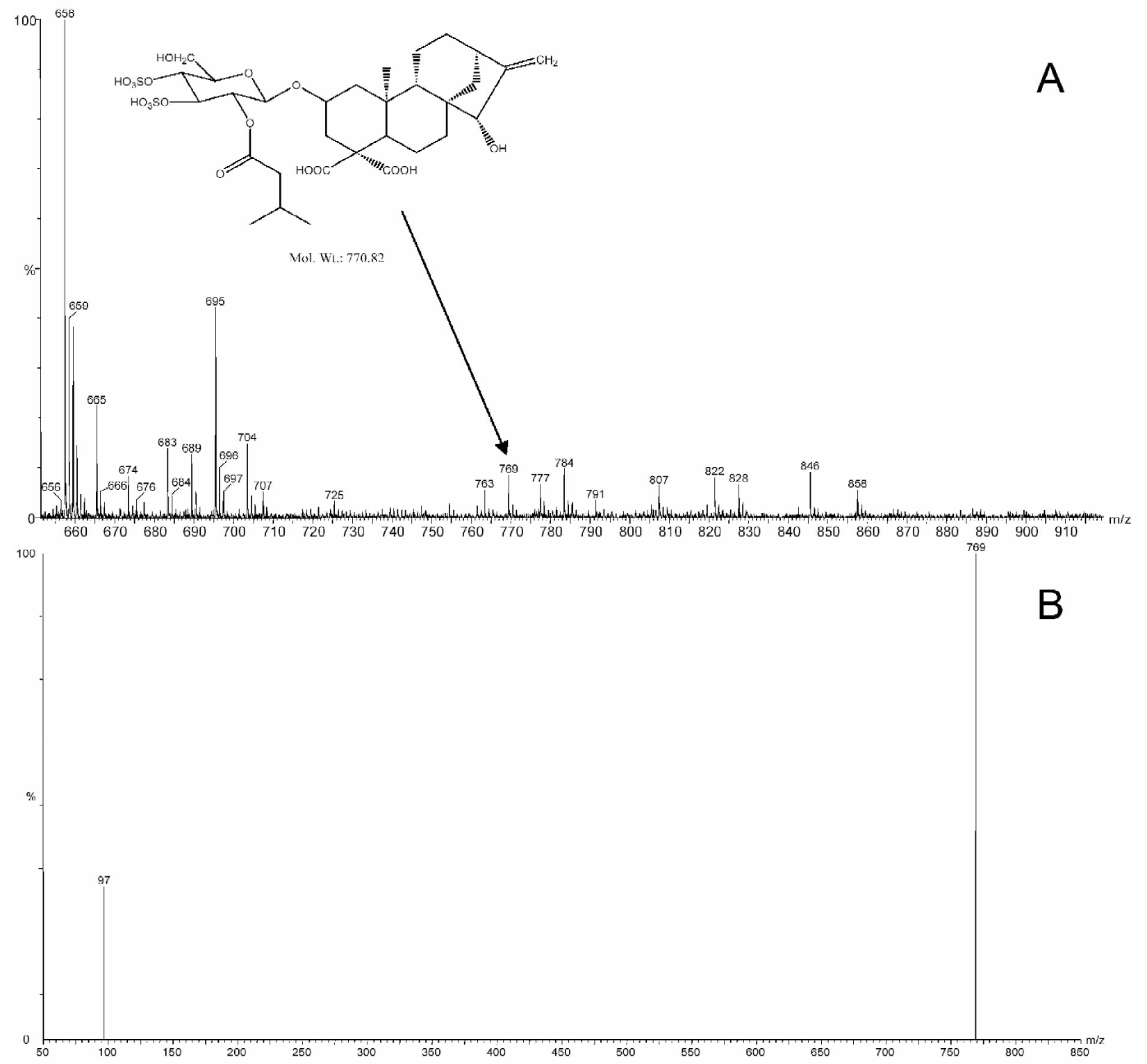

FIGURE 1. (A) ESI-MS of Xanthium strumarium seed extract and (B) ESI-MS/MS of deprotonated carboxyatractyloside. 
confirms its structure since the ion is found to dissociate nearly exclusively into $\mathrm{HSO}_{4}^{-}$of $\mathrm{m} / \mathrm{z}$ 97. ESI-MS/MS monitoring indicated carboxyatractyloside was present in extracts from seeds and cotyledonary-stage leaves but not in those from adult leaves and burrs.

Carboxyatractyloside is toxic and was originally isolated from the Mediterranean thistle Atractylis gummifera, a highly selective inhibitor of the cytosolic side-specific mitochondrial ADP/ATP carrier (Huber et al., 1999). As already mentioned, previous studies have reported that $X$. strumarium induces liver damage and can be deathful; thus, care should be taken concerning the medicinal use of $X$. strumarium and only its leaves in adult stage are recommended, since the latter had strong antimicrobial activity and did not present the toxic compound.

\section{REFERENCE}

BISHT, N.P.S.; SINGH, R. Chemical investigation of the leaves of Xanthium strumarium $\mathrm{L}$. Journal of the Indian Chemistry Society, v.LIV, p.797-8, 1977.

BISHT, N.P.S.; SINGH, R. Chemical investigation of the leaves of Xanthium strumarium L. Journal of the Indian Chemistry Society, v.55, p.707-8, 1978.

BOZSA, R.C.; OLIVER. L.R. Shoot and root interference of common cocklebur (Xanthium strumarium) and soybean (Glycine max). Weed Science, v.41, p.34-7, 1993.

CHANG, S.T.; CHEN, P.F.; CHANG, S.C. Antibacterial activity of leaf essential oils and their contituents from Cinnamomum osmophloeum. Journal of Ethnopharmacology, v.77, p.123-7, 2001.

COLE, R.J. et al. Isolation and redefinition of the toxic agent from cocklebur (Xanthium strumarium). Journal of Agricultural and Food Chemistry, v.28, p.1330-2, 1980. COLODEL, E.M.; DRIEMEIER, D.; CELSO, P. Intoxicação experimental pelos frutos de Xanthium cavanillesii (Asteraceae) em bovinos. Pesquisa Veterinária Brasileira, v.21, p.31-8, 2000.

DUARTE, M.C.T. et al. Anti-Candida activity of Brazilian medicinal plants. Journal of Ethnopharmacology, v.97, p.305-11, 2005.

FAVIER, L.S. et al. Anti-ulcerogenic activity of xanthanolide sesquiterpenes from Xanthium cavanillesii in rats. Journal of Ethnopharmacology, v.100, p.260-7, 2005.

GINESTA-PERIS, E.; GARCIA-BREIJO, F.J.; PRIMOYUFERA, E. Antimicrobial activity of xanthatin from Xanthium spinosum L. Letters in Applied Microbiology, v.18, p.2068, 1994.

HAN, T. et al. New thiazinediones and other components from Xanthium strumarium. Chemistry of Natural Compounds, v.42, p.567-70, 2006.

HSU, F.L.; CHEN, Y.C.; CHENG, J.T. Caffeic acid as active principle from the fruit of Xanthium strumarium to lower plasma glucose in diabetic rats. Planta Medica, v.66, p.22830, 2000.

HUBER, T.; KLINGENBERG, M.; BEYER, K. Binding of nucleotides by the mitochondrial ADP/ATP carrier as studied by $1 \mathrm{H}$ nuclear magnetic resonance spectroscopy.
Biochemistry, v.38, p.762-9, 1999.

KIM, I.T. et al. Methanol extract of Xanthium strumarium L. possesses anti-inflammatory and anti-nociceptive activities. Biological and Pharmaceutical Bulletin, v.28, p.94-100, 2005.

$\mathrm{KIM}$, Y.S. et al. Two cytotoxic sesquiterpene lactones from the leaves of Xanthium strumarium and their in vitro inhibitory activity on farnesyltransferase. Planta Medica, v.69, p.375-7, 2003.

LAVAULT, M. et al. Antileishmanial and antifungal activities of xanthanolides isolated from Xanthium macrocarpum. Fitoterapia, v.76, p.363-6, 2005.

LORETTI, A.P. et al. Intoxicação experimental pelos frutos de Xanthium cavanillesii (Asteraceae) em ovinos. Pesquisa Veterinária Brasileira, v.19, p.71-8, 1999.

MANDAL, S.C. et al. Neuropharmacological activity of Xanthium strumarium Linn. extract. Journal of Herbs, Spices and Medicinal Plants, v.8, p.69-77, 2001.

NATIONAL COMMITTEE FOR CLINICAL LABORATORY STANDARDS. Methods for dilution antimicrobial susceptibility tests for bacteria that grow aerobically. Approved Standard. 6.ed. Wayne: NCCLS, 2003.

NIEVES, L.J. et al. Efecto diurético del Xanthium strumarium L. (Guizazo de Caballo). Revista Cubana de Plantas Medicinales, v.1, p.22-5, 1999.

QIN, L. et al. A new thiazinedione from Xanthium strumarium. Fitoterapia, v.77, p.245-6, 2006.

RISCALA, E.C. et al. Xanthanolides and a bisnorxanthanolide from Xanthium cavanillesii. Phytochemistry, v.35, p.1588-9, 1994.

SCHERER, R.; SISMOTTO, M.; GODOY, H.T. Antioxidant activity and related compounds of Xanthium strumarium extracts. Phytochemistry, 2009. Accepted nov. 2008.

SCOTT, J.S.; LAPIDUS, R.; SOKOLOVE, P.M. Use of carboxyatractylate and tight-binding inhibitor theory to determine the concentration of functional mitochondrial adenine nucleotide translocators. Analytical Biochemistry, v.210, p.69-76, 1993.

SHARMA, S.R. et al. Anthelmintic activity of Xanthium strumarium against Haemonchus contortus infection in sheep. Indian Journal of Animal Sciences, v.73, p.342-4, 2003.

SHEU, S.J. et al. Determination of xanthii constituents by high-performance liquid chromatography and capillary electrophoresis. Journal of Food and Drug Analysis, v.11, p.67-71, 2003.

STUART, B.P.; COLE, R.J.; GOSSER, H.S. Cocklebur (Xanthium strumarium var. strumarium) intoxication in swine: review and redefinition of the toxic principle. Veterinary Pathology, v.18, p.368-83, 1981.

TAHER, H.A.; UBIERGO, G.O.; TALENTI, E.C.J. Constituents of the essential oil of Xanthium strumarium. Journal of Natural Products, v.48, p.857-7, 1985.

TALAKAL, T.S.; DWIVEDI, S.K.; SHARMA, S.R. In vitro and in vivo antitrypanosomal activity of Xanthium strumarium leaves. Journal of Ethnopharmacology, v.49, p.141-5, 1995.

TURGUT, M. et al. Carboxyatractyloside poisoning in humans. Annals of Tropical Pediatrics, v.25, p.125-34, 2005.

YADAVA, R.N.; JHARBADE, J. Novel biologically active triterpenoid saponin from the leaves of Xanthium strumarium Linn. Asian Journal of Chemistry, v.19, p.1224-30, 2007. 